\title{
Proliferating Cell Nuclear Antigen Measurement
}

National Cancer Institute

\section{Source}

National Cancer Institute. Proliferating Cell Nuclear Antigen Measurement. NCI

Thesaurus. Code C120646.

The determination of the proliferating cell nuclear antigen present in a sample. 